\title{
APPLICATION OF THERMAL PLASMA FOR INERTIZATION OF SLUDGE PRODUCED DURING TREATMENT OF LANDFILL LEACHATE
}

\author{
Anelise Leal Vieira Cubas, ${ }^{a}$, , Marina de Medeiros Machado ${ }^{\text {a }}$, Marilia de Medeiros Machado ${ }^{\mathrm{a}}$, Elisa Helena Siegel Moecke, \\ Ana Regina de Aguiar Dutra ${ }^{b}$, Haidi Fiedler ${ }^{c}$ Priscila Bueno \\ ${ }^{a}$ Departamento de Engenharia Ambiental, Universidade do Sul de Santa Catarina, Av. Pedra Branca, 25, 800137-270 Palhoça - \\ SC, Brasil \\ bDepartamento de Engenharia de Produção, Universidade do Sul de Santa Catarina, Av. Pedra Branca, 25, 800137-270 Palhoça \\ - SC, Brasil \\ 'Departamento de Química, Universidade Federal de Santa Catarina, Campus Reitor João David Ferreira Lima, 88040-900 \\ Florianópolis - SC, Brasil
}

Recebido em 01/12/2015; aceito em 25/05/2016; publicado na web em 01/08/2016

\begin{abstract}
One of the outstanding issues of concern by governments and society in general relates to the final destination of solid waste, which can bring severe impacts on social, political, economic and environmental dimensions. The sustainable development of enterprises and industries goes for the care of the planet, thus ensuring the quality of life for future generations and the planet. The disposal of municipal waste in landfills is the technique most commonly employed for the remediation of solid residues. The residues undergo decomposition beneath the soil and in the presence of water this generates leachate, which percolates down to the bottom of the landfill through drainage. This drained liquid is collected from the landfill installations and subjected to treatment, which involves physico-chemical and biological processes. Landfill leachate commonly contains heavy metals due to the incorrect disposal of products such as fluorescent bulbs and batteries. In this context, a method for the treatment of sludge originating from the physicochemical remediation of leachate using thermal plasma is proposed in this paper. The efficiency of the method was verified by monitoring the total organic carbon content, water content and density of the sludge. The quantity of metals present in the samples was determined before and after pyrolysis by thermal plasma using flame atomic absorption spectroscopy (FAAS), scanning electron microscopy (SEM) and X-ray fluorescence (XRF) spectrometry techniques. The results show that the leachate treatment method used was efficient, presenting the best results for the samples of iron and zinc.
\end{abstract}

Keywords: landfill leachate; sludge; thermal plasma.

\section{INTRODUCTION}

Increased consumerism, mainly due to easily available credit and globalization, leads to solid residues being generated in greater amounts and with different characteristics, particularly in big cities. The relevant authorities therefore need to find solutions for the appropriate disposal of these residues considering the associated social, political, economic and environmental issues. In this context, landfills represent an environmentally acceptable destination for solid residues.

Landfill remains the most commonly used method for the final disposal of urban solid residues in many countries, due to its economic advantages and easy management. In a landfill, the residues are placed in layers over soil which has been rendered impermeable. These layers are compressed to reduce their volume and periodically covered with appropriate material. The degradation of the organic fraction of the residues combined with the percolation of rainwater through the landfill produces a liquid called "leachate". This is a dark liquid with an unpleasant smell which contains high loads of organic solids and inorganic substances (associated with the water) as well as the products resulting from the digestion of organic matter by autochthonous microorganisms. ${ }^{1,2}$ Due to the recalcitrant characteristics of this leachate, its treatment has been extensively studied and a vast amount of relevant literature is available. ${ }^{3-9}$

According to environmental regulations, the conditions and standards established for the discharge of effluent to water bodies must be adhered to. Thus, leachate cannot be discharged to natural

\footnotetext{
*e-mail: anelise.cubas@unisul.br
}

water bodies without appropriate treatment since it contains high concentrations of pollutants, such as organic substances (evaluated through the chemical oxygen demand (COD) and biochemical oxygen demand (BOD)), ammonia, heavy metals and inorganic salts. ${ }^{7,10,11} \mathrm{As}$ a landfill ages (> 10 years) the biodegradable fraction leached from organic pollutants decreases, since anaerobic decomposition occurs in the landfill. As a result, the organic compounds present in mature leachate are much more refractory than those found in leachate present in more recently established landfill sites..$^{2,4,5,12,13}$ One of the main disadvantages associated with the different leachate treatments is the generation of a considerable volume of sludge comprised of recalcitrant material. ${ }^{14,15}$

In Brazil, the most common form for landfill leachate treatment is biological, because it is an effective method for treating materials rich in volatile fatty acids and high value of Biochemical Oxygen Demand (BOD). ${ }^{16,17}$

However, several problems are detected in the leachate treatment of older cells (mature slurry), since, in general, it is believed that the permanence of high molecular weight compounds in landfill leachate is one of the factors responsible for the reduction considerable biodegradability (determined by the ratio BOD/COD). ${ }^{18}$

Thus, since there are no economically viable processes that reduce all environmentally relevant parameters of the slurry matrix, several studies have proposed the use of integrated processes such as, for example, Morais et al., which deals with the photocatalytic treatment as pretreatment of slurry system samples, to increase their aerobic biodegradation. ${ }^{19}$ There is also the paper of Caramão et al., which uses SPE technique for the extraction of organic compounds of 
low and medium polarity present on sanitary landfill leachate, using $\mathrm{XAD}-4$ polymeric resin as the stationary phase and identification by attempting, components of the organic extract, via library GC/MS system..$^{20}$ Bertazzoli and Pellegrini also studied the photoelectrochemical process in pilot scale, in the treatment of solutions that are characterized by high concentration of pollutants species and strong staining, as the aqueous effluent from municipal landfills. ${ }^{21}$

In view of the various types of advanced processes for leachate treatment, the aim of this study was to apply a treatment method for leachate sludge involving the thermal plasma technique in which the inertization of metals into a vitreous silicate form occurs. This type of treatment allows the inertization of the heavy metals present in the leachate sludge and the reduction of its volume so that smaller landfill areas will be required.

The term thermal plasma is used to describe gases which are partially ionized when heated at high temperatures $(5,000$ to $50,000 \mathrm{~K})$, at pressure close to atmospheric pressure. Non-equilibrium plasmas are low pressure plasmas characterized by high electron temperatures and low ion and neutral temperatures. ${ }^{22}$

Anyaegbunam has been actively working in the research and developmental efforts undertaken to establish plasma technology as an efficient, economical, and safe hazardous waste destruction tool. This paper outlines the high tech thermal plasma processes and tries to establish the technology as a uniquely efficient tool in hazardous waste destruction, such as hospital wastes, pyrotechnic smoke assemblies, thermal batteries, and contaminated soil which may be met through utilization of Military Tools. Results show that thermal plasma processes are effective in hazardous waste treatment and environmental remediation. ${ }^{23}$

In the case of thermal plasma, the interaction between the working gas (generally argon) and the high intensity electric arc occurs through two electrodes, where a potential difference is established between them and high current is applied. These devices are referred to plasma torches. There are several types of plasma torch and they can be classified according to their power supply (direct current (DC) arc torch, induction torch and high frequency capacitive torch) $)^{24,25}$ or according to the type of arc (non-transferred arc and transferred arc).

The operational principle is the same for non-transferred and transferred arcs and is based on the forced convection of the gas through the column of an electric arc established between two electrodes (anode and cathode) applying a direct or alternating current. The main difference relates to the position of the electrodes. In the case of a transferred arc, the anode and cathode are separated, one electrode being the emitter and the receiver of the arc is located outside the torch, which can be another electrode or the material being heated interlinked with the circuit via an electrode. In this type of torch, the plasma arc is formed between the electrode inside the torch (cathode) and the piece or material to be processed, which serves as the anode. These torches operate with high electric currents and low gas flows, generally of argon or nitrogen. ${ }^{22}$

In this study, thermal plasma torches of the transferred arc type were used to carry out the experiments. The operational principle is based on forced convection of the gas through the column of an electric arc established between two electrodes (anode and cathode) applying a direct current. The cathode lies within the torch and the anode outside the torch, at the place where the material to be inerted is deposited. ${ }^{26}$

The efficiency of the elimination of residues by thermal plasma is recognized worldwide and the application of this technology to deal with several types of wastes is extensively reported in the literature, including municipal residues, ${ }^{27-33}$ incinerator ash, ${ }^{34-36}$ galvanic sludge,${ }^{29,37}$ oily sludge produced by refineries, ${ }^{38}$ and sludge generated during effluent treatment, hazardous residues, ${ }^{39}$ and gases ${ }^{40,41}$ In many studies, the inert material obtained after undergoing the thermal plasma is transformed into other materials with added value, such as fiberglass and carbon black. ${ }^{42,43}$

Advances in the use of plasma for the treatment of waste are evident in different studies. The creation of regulatory guidelines, economic and socio-political in the countries are promoting the adoption of advanced thermal conversion techniques such as thermal plasma technology and these are expected to become increasingly commercially viable in the future. ${ }^{28}$ To support the discussion of the application of the thermal plasma, Chen et al. studied the production of glass-ceramics from incineration ash using thermal plasma in laboratory and pilot scales. The glass-ceramics produced from incineration ash show great potential for reuse as the water permeable material or non-porous. ${ }^{44}$

The use of thermal plasma for the destruction of industrial solid residues has increased in many countries, including Japan,,$^{34,44-47}$ because the high plasma temperatures cause the rapid and complete inerting of organic substances and can also result in the fusion and vitrification of certain inorganic residues. ${ }^{48}$ These applications show that the use of thermal plasma technology for the final treatment of hazardous waste is very attractive. It is considered to be a clean and environmentally safe option, since it renders the hazardous components of residues inert and reduces the gas emissions. Thus, with this technique the environmental impact and risk to human health associated with these residues is minimized or even eliminated.

In this study, the quantity of metals ( $\mathrm{Fe}$ and $\mathrm{Zn}$ ) present in the samples was determined before and after undergoing the thermal plasma using flame atomic absorption spectroscopy (FAAS), scanning electron microscopy (SEM) and X-ray fluorescence (XRF) spectrometry techniques.

\section{EXPERIMENTAL SECTION}

\section{Sample characterization}

The characterization of sludge samples originating from the physicochemical treatment of landfill leachate was carried out by weighing out, using a precision weighing balance (OHAUS model AS 200), $0.5 \mathrm{~g}$ of the sludge residue, previously dried in a muffle oven at $100{ }^{\circ} \mathrm{C}$, and adding $20 \mathrm{~mL}$ of distilled water and $20 \mathrm{~mL}$ of concentrated nitric acid. The solution was filtered prior to analysis and the iron and zinc contents were determined by FAAS.

The Total Organic Carbon (TOC) content was determined using the method described by Zhu et al. ${ }^{49}$ The samples were dried at 45 ${ }^{\circ} \mathrm{C}$ and passed through a $2 \mathrm{~mm}$ sieve. To duplicate samples $(0.5 \mathrm{~g})$ $15 \mathrm{~mL}$ of $1.25 \mathrm{~mol} \mathrm{~L}-1$ potassium dichromate $\left(\mathrm{K}_{2} \mathrm{Cr}_{2} \mathrm{O}_{7}\right)$ and $30 \mathrm{~mL}$ of concentrated sulfuric acid $\left(\mathrm{H}_{2} \mathrm{SO}_{4}\right)$ were added. The samples were heated to $150{ }^{\circ} \mathrm{C}$. After cooling, $100 \mathrm{~mL}$ of distilled water and three drops of ferroin indicator were added prior to the titration procedure. The samples were titrated with $0.50 \mathrm{~mol} \mathrm{~L}^{-1} \mathrm{FeSO}_{4}$, until the color changed from green to red.

The XRF spectrometry analysis was performed by the Laboratory of Catalysis and Interfacial Phenomena (SXRF-LACFI) of the Federal University of Santa Catarina (UFSC), Brazil, and the fluorescence measurements were performed on a Varian spectrofluorometer, model Cary Eclipse, operating with a xenon lamp and detector (80 points per second) connected to a data acquisition and processing system (Cary Eclipse version 1.1, Varian, 2002). The same equipment was used to measure the moisture content and viscosity of the raw samples.

\section{Preparation of samples for thermal plasma}

The samples were then prepared for vitrification using $3.0 \mathrm{~g}$ of the sludge originating from the physicochemical treatment of landfill 
leachate, weighed out on an analytical scale (Bel Mark 210 A) with different percentages of quartzite sand with a particle size of $<0.100$ $\mathrm{mm}$. The percentage of sand in each sample varied from 50 to $200 \%$, using $3.00 \mathrm{~g}$ of sludge (S1 - 50\% of sand; S2 $-100 \%$ of sand; S3 $200 \%$ of sand). An amount of water sufficient to moisten the sludge and sand mixture was added to each sample. Three replicates were prepared for each sand percentage.

\section{Inerting of sludge samples}

The inerting was carried out in a plasma reactor with a transferred arc torch. The reactor consists of a cathode and a graphite anode, the latter being used to support the sample. The whole system was placed inside a furnace with an opening for the collection of gases, as shown in Figure 1. Argon was used not only for the formation of the plasma but also to cool the cathode. A direct current source (ELETROMEG model RG 550), used commercially for TIG (tungsten inert gas) welding, was used to provide the high current $(\sim 200 \mathrm{~A})$ required for the gas ionization.

In this study, the plasma jet was maintained with a direct current of $200 \mathrm{~A}$ and 12 volts, equivalent to a power of $2.4 \mathrm{~kW}$, for $5 \mathrm{~min}$, using an argon gas flow of $13 \mathrm{~L} \mathrm{~min}^{-1}$ and a temperature of approximately $5000{ }^{\circ} \mathrm{C}$. The torch was positioned $4 \mathrm{~cm}$ above the anode. After the thermal plasma process, the samples were weighed once again to obtain the mass reduction after the treatment. The gases emitted during the process were collected by a hose and passed through a cleaning gas system containing a $6 \mathrm{~mol} \mathrm{~L}^{-1} \mathrm{HCl}$ solution.

\section{Leaching tests}

After the thermal plasma process, the samples were collected from the electrode support and submitted to the leaching process to evaluate the efficiency of the sludge inertization stage. The procedure was based on the Brazilian standard NBR 10005/2004. ${ }^{50}$ The rendered inert sample was transferred to a $50 \mathrm{~mL}$ beaker and $20 \mathrm{~mL}$ of distilled water was added. To ensure a leaching $\mathrm{pH}$ of 5 , a small quantity of 0.5 mol L-1 acetic acid was added for $\mathrm{pH}$ correction (Analion $\mathrm{pHmeter} \mathrm{NT}$ 2000 microprocessor). The resulting solution was stirred at 30 rotations per minute (rpm) in a bench top stirrer (NT 712 Nova Técnica) for $24 \mathrm{~h}$, followed by filtration. The solid residue was separated out and the concentrations of solubilized metals present in the solution were determined by FAAS.

\section{Flame Absorption Spectrometry Analysis}

For the characterization of the raw sludge, the leachate samples and the gas cleaning solution, an atomic absorption spectrometer (Buck Scientific 200 A obtained from Cole Parmer) was used, employing hollow cathode lamps for iron and zinc and air-acetylene flows of $8 \mathrm{~L} \mathrm{~min}^{-1}$ and $4 \mathrm{~L} \mathrm{~min}^{-1}$. The standard solutions used in the analysis were $0,2.5,5.0,7.5$ and $10 \mathrm{mg} \mathrm{L}^{-1} \mathrm{Fe}$ and $0,0.1,0.2,0.3$ and $0.4 \mathrm{mg} \mathrm{L}^{-1} \mathrm{Zn}$. The following conditions were applied for the optimization of the zinc determination by FAAS: blue oxidizing flame; wavelength $213.9 \mathrm{~nm}$; sensitivity $0.018 \mathrm{mg} \mathrm{L}^{-1}$ (IUPAC, 1994); hollow cathode lamp current $7.5 \mathrm{~A}$; and gas mixture air-acetylene; and for iron determination: blue oxidizing flame; wavelength 213.9 nm; sensitivity $0.10 \mathrm{mg} \mathrm{L}^{-1}$ (IUPAC, 1994); $;{ }^{51}$ hollow cathode lamp current $15 \mathrm{~mA}$; and gas mixture air-acetylene.

\section{Scanning Electron Microscopy Analysis}

The SEM analysis was carried out on samples in their raw state and after thermal plasma process, using Scanning electron microscope JEOL JSM-6390LV. Using this technique it was possible to determine the chemical composition of the samples and also to visualize the surfaces of the crystals in order to evaluate the homogeneity of the vitreous matrix. The samples to be analyzed must be macerated to make them into small fragments and to adapt to the circular cross section of sample holder approximately $2.5 \mathrm{~cm}$ in diameter and the maximum height of $2.0 \mathrm{~cm}$.

\section{X-Ray Fluorescence Spectrometry}

An X-ray fluorescence spectrometer (S2 Ranger - Bruker) was used to analyze the raw and treated samples. The samples were prepared in the form of pellets, for which they required grinding, the addition of $0.5 \mathrm{~g}$ of boric acid (as a binder) with $6 \mathrm{~g}$ of boric acid for the incorporation the raw sludge, and $0.125 \mathrm{~g}$ of boric acid (as a binder) with $7.375 \mathrm{~g}$ of boric acid for the incorporation of the post-inertization sludge sample. The mass difference is due to the quantity of sample available for analysis, the quantity of post-inertization sample being reduced because of the mass reduction by thermal plasma. In addition, in the analysis of the raw and post-inertization sludge, the organic matter content was considered using the loss on ignition technique, for which $1.0 \mathrm{~g}$ of raw sludge sample and $0.5 \mathrm{~g}$ of
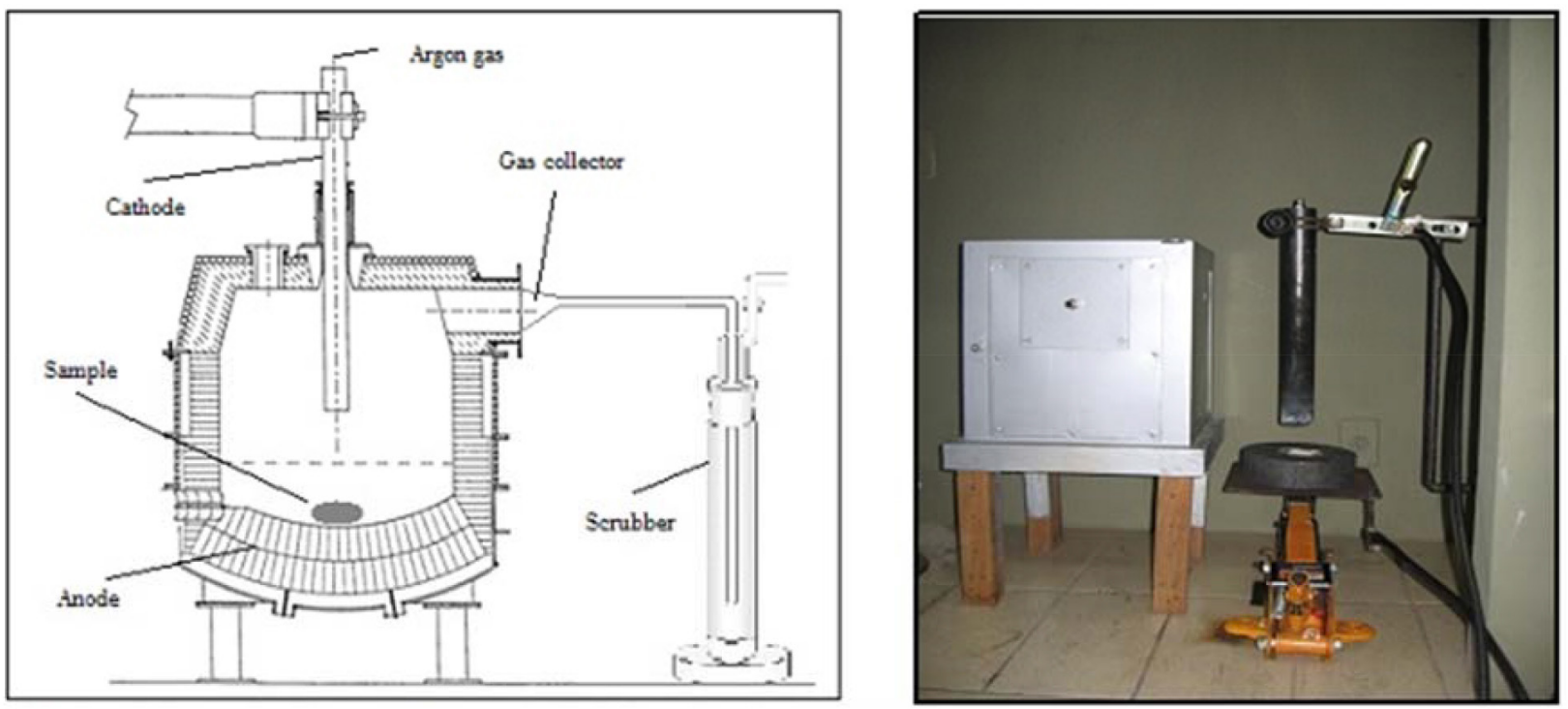

Figure 1. Furnace in which the transferred arc plasma torch was placed 
inerted sludge sample were used. The samples were kept in a muffle oven at $105^{\circ} \mathrm{C}$ for $1 \mathrm{~h}$, and then weighed again to obtain the sample moisture content. The samples were then kept for $2 \mathrm{~h}$ in a muffle oven at $440{ }^{\circ} \mathrm{C}$, and weighed again to obtain the organic matter content.

\section{RESULTS AND DISCUSSION}

\section{Analysis of raw sludge samples}

The moisture content of the raw sludge sample was verified according to the Standard Methods ${ }^{52}$ and the samples were found to contain $18.5 \%$ of water. The TOC content of the raw sludge sample, quantified according to the literature, ${ }^{53}$ was found to be $4.05 \%$.

The results for the analysis of the raw leachate sludge, considering dilution factor, by atomic absorption indicated concentrations of $8.912 \mathrm{mg} \mathrm{L}^{-1}$ for iron and $0.801 \mathrm{mg} \mathrm{L}^{-1}$ for zinc. The concentrations are presented as $\mathrm{mg} \mathrm{L}^{-1}$ of liquid sample.

The results obtained for the SEM analysis of the raw samples are shown in Figure 2. It can be observed that the elements present in highest proportions in the sludge are carbon, oxygen (22\%), chromium $(20.9 \%)$ and chloride $(11 \%)$. Since the sludge composition is mainly due to the type of residues discharged to the landfill site, a wide diversity in the compositions is expected.

Table 1 and Figure 3 presents the spectrograms of the most stable elements in the raw sludge sample $1 \mathrm{~A}$ obtained by XRF. It was possible to identify some elements: $\mathrm{Cr}, \mathrm{Al}, \mathrm{Cl}, \mathrm{K}, \mathrm{Ca}, \mathrm{Ni}, \mathrm{Na}, \mathrm{Mg}$, $\mathrm{Si}, \mathrm{Zn}, \mathrm{Mn}, \mathrm{S}, \mathrm{Co}$ and $\mathrm{Cu}$. Also, it was noted that the loss on ignition (LOI) was high $(40.80 \%)$, possibly because of the water content in the sample, since LOI relates to the mass loss of a residue on ignition (heated in an atmosphere of oxygen or air at high temperatures). The observed mass decrease of the sample may be attributed mainly to water loss as well as a loss of carbon and sulfur resulting from the expulsion of all the water from the sample, a loss of carbon dioxide from carbonates and/or the conversion of metal sulfides into metal oxides and sulfates and sulfur oxides, and other chemical reactions.

The metals may be derived from natural geochemistry processes (weathering),${ }^{54}$ such as iron, one of the most abundant elements on the Earth's crust, which compounds can be found in all water bodies, even at concentrations reduced. ${ }^{55}$ However, the contribution attributed to human activities has been highlighted, for example, those related to surface runoff in agricultural areas, which contribute to the agrochemical supply and metal species to water bodies. ${ }^{56}$

In this way the presence of iron in the raw samples are also due to a significant amount of this metal in Brazilian soils. ${ }^{57,58}$ This amount of iron is due to the characteristic of soils rich in hematite $\left(\mathrm{Fe}_{2} \mathrm{O}_{3}\right)$, magnetite $\left(\mathrm{Fe}_{3} \mathrm{O}_{4}\right)$, olivine $\left((\mathrm{MgFe})_{2} \mathrm{SiO}_{4}\right)$, limotita $\left(\mathrm{Fe}(\mathrm{OH})_{3} \cdot \mathrm{nH}_{2} \mathrm{O}\right)$, among others. ${ }^{59}$
The metals $\mathrm{Al}$ and $\mathrm{Cr}$ appeared in equal amounts to $1.11 \%$ in the SEM analysis and $\pm 0.33 \%$ in XRF analysis for Al, and $20.9 \%$ in the SEM analysis and $\pm 9.98 \%$ in XRF analysis for Cr. As the sample is a landfill sludge, and waste from the landfill are of different nature, the presence of these metals reflects the diversity of slurry sludge sample.

\section{Thermal Plasma process}

In the treatment of the leachate sludge by thermal plasma, the samples were fused together with sand (silicate) at a temperature of approximately $5000{ }^{\circ} \mathrm{C}$, and in this stage the silicate was transformed into the liquid phase. After solidification, the samples had the appearance of a vitreous material, as seen in Figure 4.

On exposure of the samples to the thermal plasma, the organic chemical elements are broken down, and also the inert residue is completely dehydrated. Thus, there is a considerable reduction in the sample mass, as shown in Table 2 . In order to quantify this reduction in percentage terms, the mass of the vitreous sample is deducted from the real mass (considered as the initial sample mass).

According to Table 2, the best result of mass reduction was in sample with $50 \%$ of sand (S1), which achieves a reduction of $74.53 \%$. These results show that for samples with higher quantities of sand (S3), the mass reduction is lower (Table 2), because the silicate is responsible for the vitrification of the samples and the sand does not volatilize and encapsulates the metals present in the samples, therefore the amount of clay is greater in samples with higher amounts of sand.

In the case of leachate sludge, the reduction in the mass of the samples has several benefits, considering the problems associated with landfills related to the area available and the saturation of the landfill capacity. This could lead to an important reduction in the landfill areas designated for leachate sludge and/or the useful lifetime of the landfill.

According to the results obtained, there was a significant reduction in the iron and zinc leached after vitrification by thermal plasma, for all percentages of sand added to the samples, in comparison to the raw sludge (Table 2). All of the samples presented $100 \%$ efficiency. Data on the metal concentrations in the solution resulting from the leaching of these samples are below the limits for iron and zinc established by the Brazilian National Environment Council (Conselho Nacional de Meio Ambiente - CONAMA) through Resolution n. 430/2011, ${ }^{60}$ for effluent discharge, since the values were under the LOD.

In the thermal plasma treatment, the sludge sample is exposed to very high temperatures, and thus the partial volatilization of metals present in the residue (iron and zinc) occurs before the vitrification of the samples.

Therefore, the use of a gas cleaning process is essential. Table 3 shows the results for the FAAS analysis of the gas cleaning solution.

Full scale counts: 1162

chorume bruto(1)_pt1

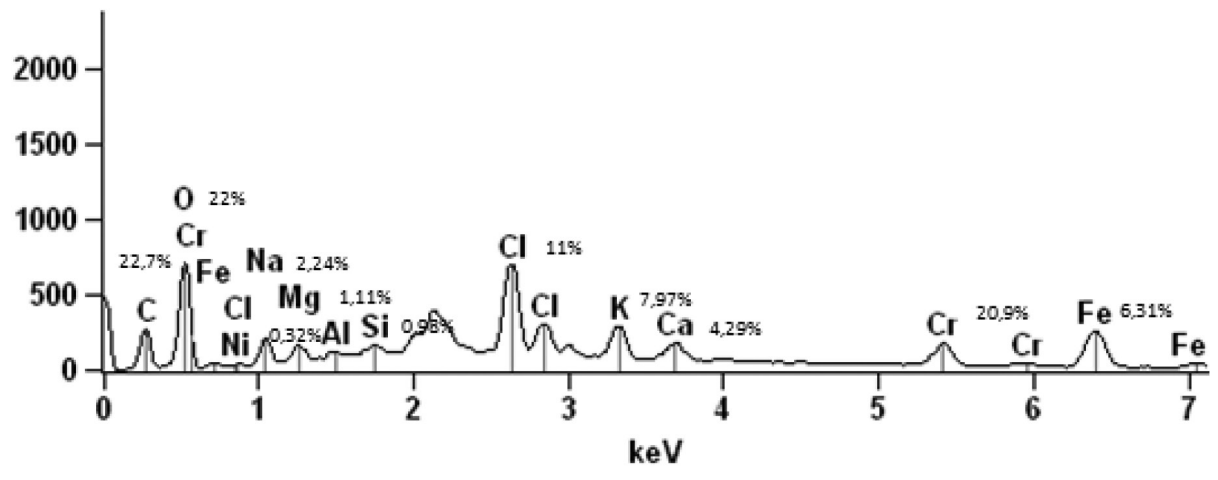

Figure 2. Results for scanning electron microscopy analysis (SEM) of raw sludge sample 
Table 1. X-ray fluorescence analysis of raw sludge sample

\begin{tabular}{|c|c|c|c|}
\hline Elemental Composition $n=2$ & Sample 1A (\%) & Sample 1B (\%) & $\begin{array}{l}\text { Mass fraction; dry basis } \\
\text { Average } \pm \text { Uncertainty }(\%)\end{array}$ \\
\hline Total $\mathrm{Fe}$ expressed as $\mathrm{Fe}_{2} \mathrm{O}_{3}$ & 40.46 & 40.31 & $40.39 \pm 0.11$ \\
\hline Total $\mathrm{Cr}$ expressed as $\mathrm{Cr}_{2} \mathrm{O}_{3}$ & 9.82 & 10.14 & $9.98 \pm 0.23$ \\
\hline Total Ni expressed as $\mathrm{NiO}$ & 3.74 & 3.64 & $3.69 \pm 0.07$ \\
\hline Total $\mathrm{Si}$ expressed as $\mathrm{SiO}_{2}$ & 1.17 & 1.23 & $1.20 \pm 0.04$ \\
\hline Total $\mathrm{Zn}$ expressed as $\mathrm{ZnO}$ & 0.85 & 0.84 & $0.85 \pm 0.01$ \\
\hline Total Mn expressed as MnO & 0.68 & 0.66 & $0.67 \pm 0.01$ \\
\hline Total $\mathrm{Cl}$ expressed as $\mathrm{Cl}$ & 0.59 & 0.56 & $0.58 \pm 0.02$ \\
\hline Total $\mathrm{S}$ expressed as $\mathrm{SO}_{3}$ & 0.55 & 0.55 & $0.55 \pm 0.01$ \\
\hline Total Al expressed as $\mathrm{Al}_{2} \mathrm{O}_{3}$ & 0.39 & 0.27 & $0.33 \pm 0.08$ \\
\hline Total Ca expressed as $\mathrm{CaO}$ & 0.31 & 0.26 & $0.29 \pm 0.04$ \\
\hline Total Co expressed as $\mathrm{CoO}$ & 0.22 & 0.22 & $0.22 \pm 0.01$ \\
\hline Total $\mathrm{K}$ expressed as $\mathrm{K}_{2} \mathrm{O}$ & 0.15 & 0.19 & $0.19 \pm 0.01$ \\
\hline Total $\mathrm{Cu}$ expressed as $\mathrm{CuO}$ & 0.15 & 0.15 & $0.13 \pm 0.01$ \\
\hline Total $\mathrm{V}$ expressed as $\mathrm{V}_{2} \mathrm{O}_{5}$ & $\leq 0.09$ & 0.18 & $\leq 0.09$ \\
\hline Mineral Part & - & - & $59.16 \pm 0.65$ \\
\hline $\begin{array}{l}\text { LOI }(n=3) \\
750{ }^{\circ} \mathrm{C}\end{array}$ & - & - & $40.80 \pm 1.02$ \\
\hline Sum: & & & $99.96 \pm 1.67$ \\
\hline
\end{tabular}

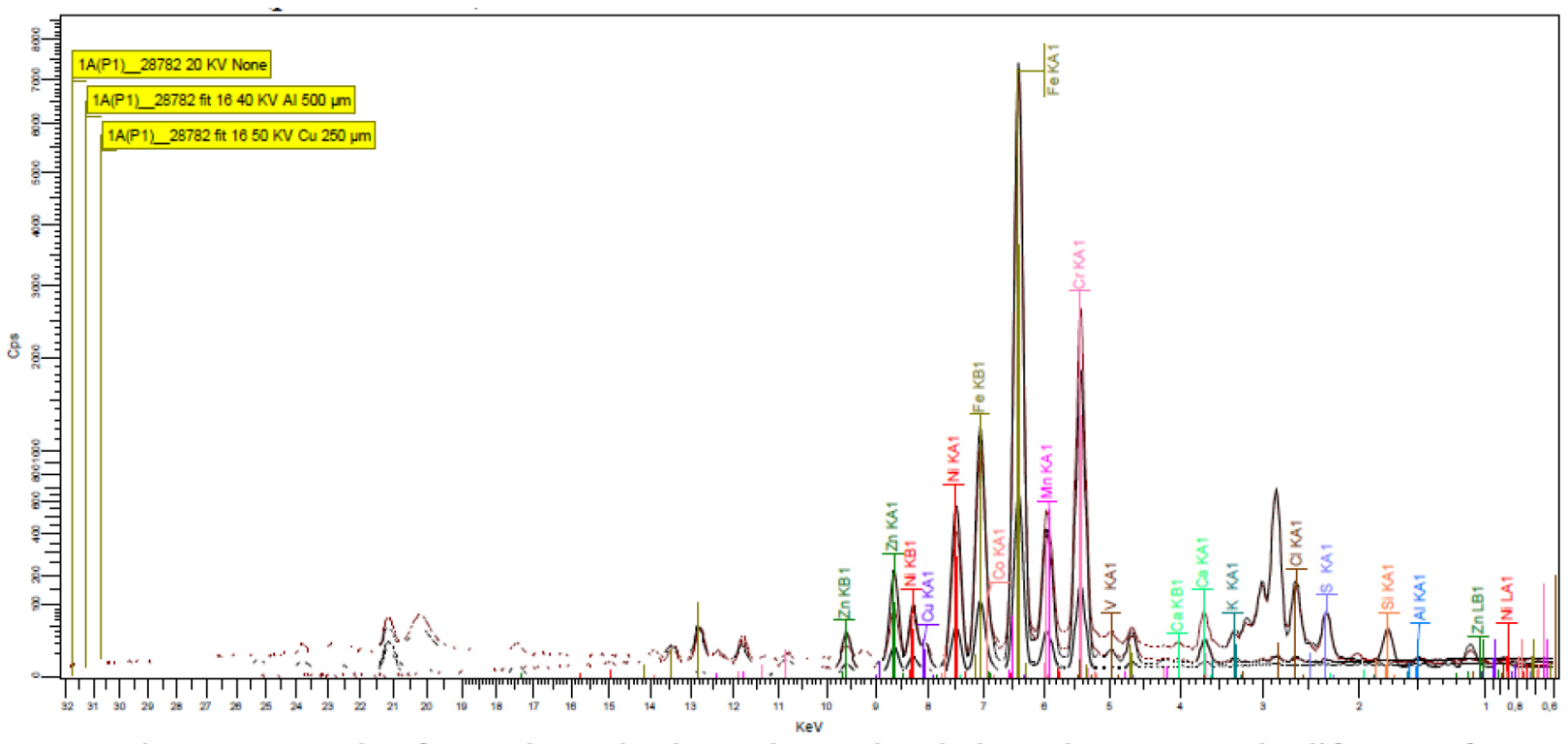

Figure 3. Spectrograms of the most stable elements in the raw sludge sample 1A obtained by XRF

According to the data reported herein, it can be observed that there was a greater volatilization of metals for the $\mathrm{Si} 2$ sample, with a 1:1 sand to sludge ratio. Considering that the addition of sand to the sludge before the thermal plasma process tends to reduce the volatilization of the metals analyzed, because the sand does not volatilize and encapsulates the metals present in the samples, therefore the amount of clay is greater in samples with higher amounts of sand, the $\mathrm{Si} 3$ sample should present better results. This was found in the case of zinc, this sample (Sz3) presenting the lowest value for metal volatilization. However, the same was not observed for iron, the highest value for volatilization being obtained for the $\mathrm{Si} 2$ sample. These results could be attributed to experimental variation in parameters such as the exposure time of the sample to the plasma, a lack of complete stability of the plasma during the process, or even contamination of the sample container.

The scanning electron microscopy (SEM) analysis of the samples was performed after the thermal plasma process, and the results for the chemical composition of the samples are shown in Figure 5. The SEM analysis also allowed the visualization of the surfaces of the crystals and an evaluation of the homogeneity of the vitreous matrix. In Figure 5 a reduction in $\mathrm{C}, \mathrm{O}, \mathrm{CI}$ and $\mathrm{Mg}$ after the thermal plasma treatment can be observed. In addition, the elements $\mathrm{Cr}, \mathrm{K}, \mathrm{Fe}$ and Na which were present in the raw sludge samples, were not observed in the inerted samples. This may be due to their sublimation and incorporation by vitrification during the thermal plasma process. The presence of silicon is due to the addition of sand during the preparation 


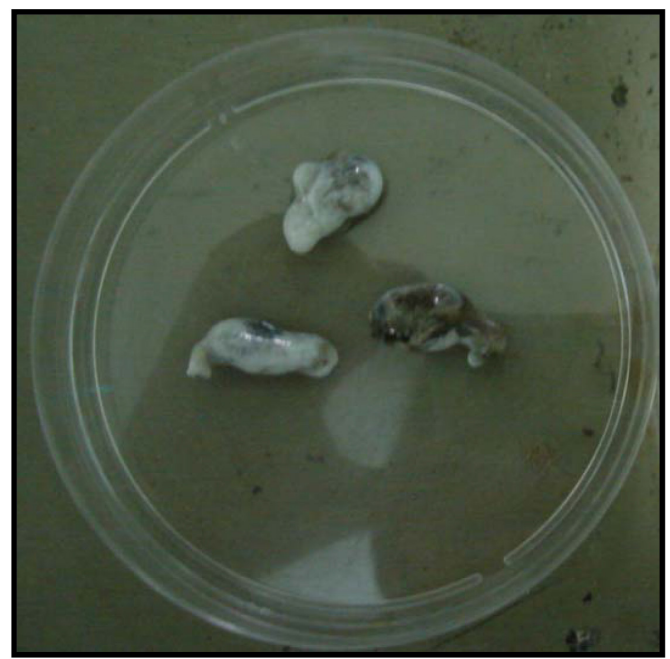

Figure 4. Vitrified sample

Table 2. Reduction percentage in the sample mass after thermal plasma treatment

\begin{tabular}{cccc}
\hline \multicolumn{4}{c}{ Mass reduction } \\
\hline Sample* & $\begin{array}{c}\text { Real mass (g) } \\
\text { (before plasma } \\
\text { treatment) }\end{array}$ & $\begin{array}{c}\text { Vitreous matrix } \\
\text { mass (g) (after } \\
\text { plasma treatment) }\end{array}$ & Reduction (\%) \\
\hline S1 & 4.50 & 1.146 & 74.534 \\
S2 & 6.00 & 2.14 & 64.334 \\
S3 & 9.00 & 4.753 & 47.189 \\
\hline
\end{tabular}

* S1 $-50 \%$ of sand; S2 $-100 \%$ of sand; S3 $-200 \%$ of sand.

of the samples for thermal plasma treatment.

Table 4 and Figure 6 show the results obtained by XRF spectroscopy for the sludge sample after thermal plasma process. In Table 4 it can be observed the result of inertization of metals (quantitative) in vitrified samples after the plasma treatment. The results shows that the metals remained in inerted sand after leaching test, and the percentage of variation is due to the presence of Si introduced during inertization. The increase in $\mathrm{Si}$ is due to the addition of sand during the preparation of the samples for thermal plasma process to allow the formation of a vitreous silicate for the incorporation of metals into a vitreous structure.

Although the metals are still present, they were inertized by plasma technology, which can now be disposed of in landfills without contamination risks of environment, since it does not transfer any of its components to the environment.
Table 3. Iron and zinc volatilization during the thermal plasma treatment

\begin{tabular}{cccc}
\hline \multicolumn{4}{c}{ Iron } \\
\hline Sample* & $\begin{array}{c}\text { Raw sludge } \\
\left(\mathrm{mg} \mathrm{L}^{-1}\right)\end{array}$ & $\begin{array}{c}\text { Gas cleaning } \\
\text { solution }\left(\mathrm{mg} \mathrm{L}^{-1}\right)\end{array}$ & $\begin{array}{c}\text { Volatilized metal } \\
(\%)\end{array}$ \\
\hline Si1 & 8.912 & 1.497 & 16.78 \\
Si2 & 8.912 & 2.313 & 25.95 \\
Si3 & 8.912 & 1.936 & 21.73 \\
\hline \multicolumn{4}{c}{ Zinc } \\
\hline Sample* & Raw sludge & Gas cleaning & Volatilized metal \\
& $\left(\mathrm{mg} \mathrm{L}^{-1}\right)$ & solution $\left(\mathrm{mg} \mathrm{L}^{-1}\right)$ & $(\%)$ \\
\hline Sz1 & 0.801 & 0.331 & 41.323 \\
Sz2 & 0.801 & 0.417 & 52.06 \\
Sz3 & 0.801 & 0.216 & 26.966 \\
\hline
\end{tabular}

*Si1 - sample of iron with $50 \%$ of sand; Si2 - sample of iron with $100 \%$ of sand; Si3 - sample of iron with $200 \%$ of sand; Sz1 - sample of zinc with $50 \%$ of sand; Sz2 - sample of zinc with $100 \%$ of sand; Sz3 - sample of zinc with $200 \%$ of sand.

\section{CONCLUSION}

According to Anyaegbunam, ${ }^{23}$ a thermal plasma is an electrically conductive gas in which an important fraction of the atoms are ionized and capable of generating temperatures up to $10000^{\circ} \mathrm{C}$ near its column with appropriate high tech. The energy generated by plasma arcs has been recently applied to hazardous waste control. In addition to its ability to sustain high temperatures, other attractive plasma technology features include its flexibility to operate in either an oxidizing or reducing environment, resultant waste volume reduction, low gas throughput, and flexibility to treat a large variety of waste types.

The treatment by thermal plasma aimed at the inertization of the iron and zinc present in sludge was efficient, demonstrating 100\% efficacy in reducing the concentration of these metals in the samples. All of the samples, after exposure to the plasma, obtained values under the LOD for the iron and zinc concentrations. The inertization of iron and zinc in residues to be deposited in landfill sites has several advantages, considering that soil contamination by hazardous products is a cumulative process, while the deposition of an inert residue in soil is safer both for the environment and public health.

The presence of iron is related to the presence of this metal in Brazilian soils. The presence of other metals, such as $\mathrm{Al}$ and $\mathrm{Cr}$, which were not analyzed by FAAS, are due to the diverse nature of the slurry sludge samples, because of the variety of residues found in landfill mass.

Full scale counts: 4477

chorume pirolisado(2)_pt1

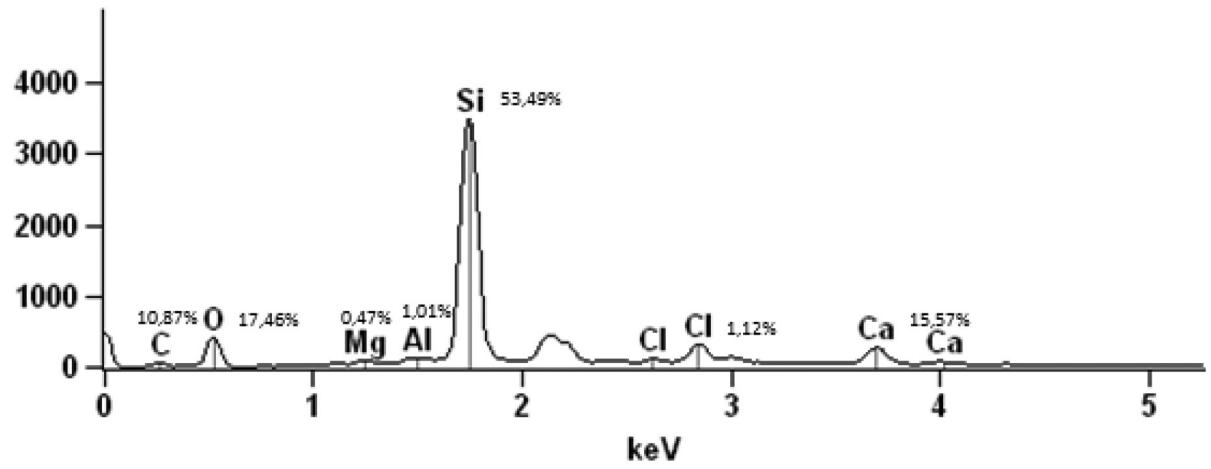

Figure 5. Results for scanning electron microscopy analysis of inerted leachate sample 


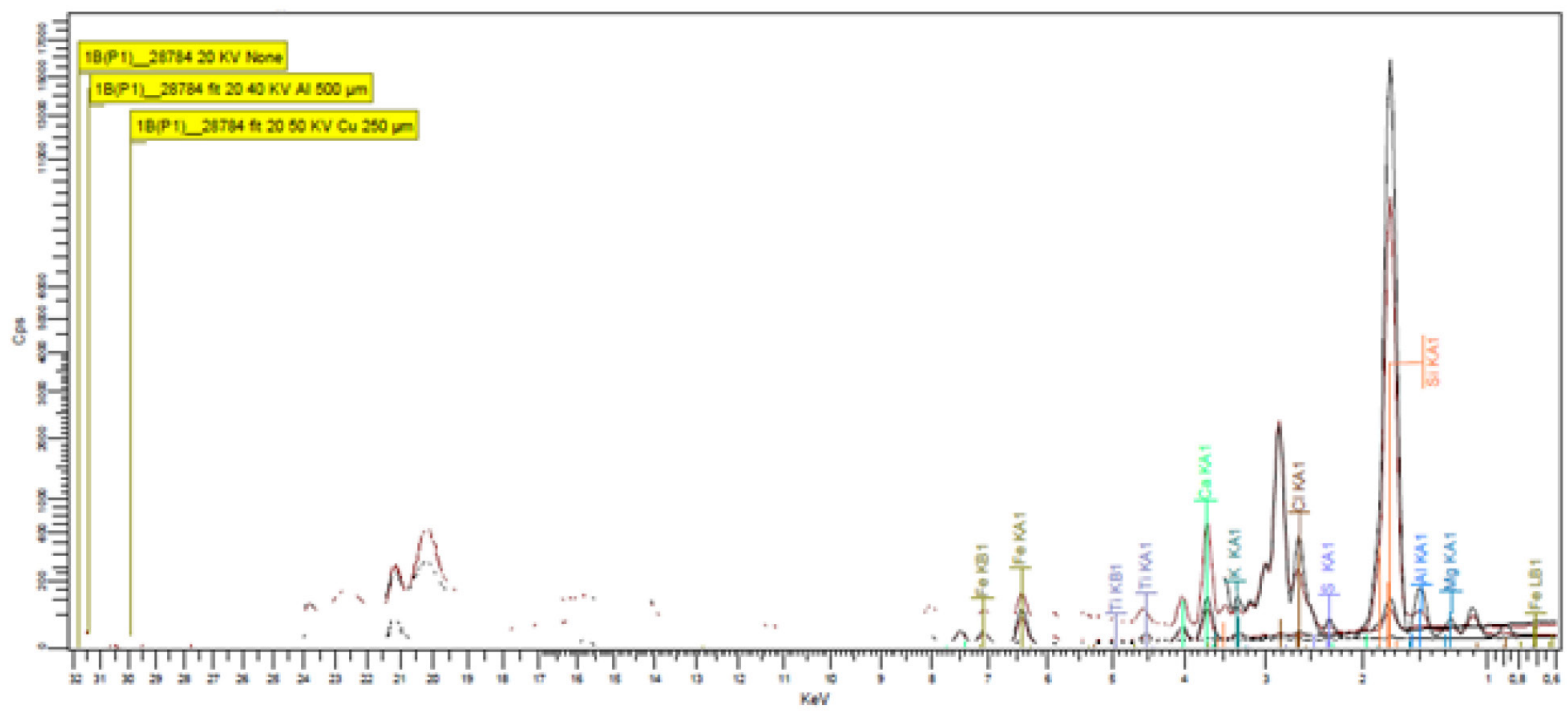

Figure 6. Spectrograms of the most stable elements in the inerted leachate sample 1A obtained by XRF

Table 4. X-ray fluorescence analysis of the inerted leachate sample

\begin{tabular}{|c|c|c|c|}
\hline Elemental Composition $\mathrm{n}=2$ & Sample 1A (\%) & Sample 1B (\%) & $\begin{array}{c}\text { Mass fraction; dry basis } \\
\text { Average } \pm \text { Uncertainty }(\%)\end{array}$ \\
\hline Total $\mathrm{Si}$ expressed as $\mathrm{SiO}_{2}$ & 91.85 & 93.04 & $92.45 \pm 0.84$ \\
\hline Total Ca expressed as $\mathrm{CaO}$ & 3.02 & 2.94 & $2.98 \pm 0.06$ \\
\hline Total $\mathrm{Al}$ expressed as $\mathrm{Al}_{2} \mathrm{O}_{3}$ & 1.62 & 1.22 & $1.42 \pm 0.28$ \\
\hline Total $\mathrm{Cl}$ expressed as $\mathrm{Cl}$ & 0.90 & 0.73 & $0.82 \pm 0.12$ \\
\hline Total Mg expressed as MgO & 0.84 & 0.40 & $0.62 \pm 0.31$ \\
\hline Total Fe expressed as $\mathrm{Fe}_{2} \mathrm{O}_{3}$ & 0.14 & 0.16 & $0.15 \pm 0.01$ \\
\hline Total $\mathrm{K}$ expressed as $\mathrm{K}_{2} \mathrm{O}$ & 0.30 & 0.27 & $0.29 \pm 0.02$ \\
\hline Total Ti expressed as $\mathrm{TiO}_{2}$ & 0.08 & 0.02 & $0.05 \pm 0.04$ \\
\hline Total $\mathrm{S}$ expressed as $\mathrm{SO}_{3}$ & 0.05 & $\leq 0.02$ & $\leq 0.02$ \\
\hline Mineral Part & - & - & $98.79 \pm 1.69$ \\
\hline $\begin{array}{l}\text { LOI }(n=3) \\
750^{\circ} \mathrm{C}\end{array}$ & - & - & $1.20 \pm 0.56$ \\
\hline Sum: & & & $99.99 \pm 2.25$ \\
\hline
\end{tabular}

All of the samples, despite containing distinct concentrations of sand, showed a high degree of metal aggregation in the vitreous matrices. The three different samples showed $100 \%$ efficacy with regard to inhibiting the leaching of the metals analyzed.

During the sludge treatment process applying thermal plasma, there is a partial volatilization of the metals, and thus the use of a gas cleaning system is essential, allowing the metals to be recovered by precipitation.

In this regard, the best results were obtained with the Si2 sample in the case of iron, wherein the $100 \%$ sand sample was not found in the leachate metal aluminum, which indicates that some degree of experimental variation may have occurred, given that the best results were expected for the $\mathrm{Si} 3$ sample, since the higher quantity of sand is expected to provide a greater reduction in the metal volatilization. The variations observed may have occurred due to the different periods for which the samples were exposed to the plasma, because the plasma arc is formed by two electrodes and the sample lies between them, although we control the exposure time of the sample to plasma (always $5 \mathrm{~min}$ ), usually in the first minutes the arch is not well stabilized, and we can not add the sample later because the arc is established along with the sample, or a lack of complete plasma stability during the thermal plasma process. In the case of zinc, as expected, the best results were obtained for the Sz3 sample, wherein $200 \%$ sand sample of zinc metal was not found in the leachate.

\section{ACKNOWLEDGEMENTS}

The authors wish to thank UNISUL and UFSC for the financial and technical support to carry out this work.

\section{REFERENCES}

1. Koshy, L.; Paris, E.; Ling, S.; Jones, T.; Bérubé, K.; Sci. Total Environ. 2007, 384, 171

2. Xie, B.; Xiong, S.; Hu, C.; Liang, S.; Zhang, X.; Lu, J.; Bioresour. Technol. 2012, 103, 71

3. Deng, Y.; Englehardt, J. D.; Water Res. 2006, 40, 3683.

4. Foo, K. Y.; Hameed, B. H.; J. Hazard. Mater. 2009, 171, 54.

5. Xie, B.; Lv, B. Y; Hu, C.; Liang, S. B.; Tang, Y.; Lu, J.; Bioresour. Technol. 2010, 101, 7754 .

6. Zhang, H.; Ran, X.; Wu, X.; Zhang, D.; J. Hazard. Mater. 2011, 188, 261. 
7. Turro, E.; Giannis, A.; Cossu, R.; Gidarakos, E.; Mantzavinosb, D.; Katsaounis, A.; J. Hazard. Mater. 2012, 207, 73.

8. Aziz, S. Q.; Aziz, H. A.; Yusoff, M. S.; Bashir, M. J. K.; J. Hazard. Mater. 2011, 189, 404.

9. Li, H.; Zhou, S.; Huang, G.; Xu, B.; Process Saf. Environ. 2013, 91, 285.

10. Zhao, X.; Qu, J.; Liu, H.; Wang, C.; Xiao, S.; Liu, R.; Liu, P.; Lan, H.; Hu, C.; Bioresour. Technol. 2010, 101, 865.

11. Vedrenne, M.; Vasquez-Medrano R.; Prato-Garcia, D.; Frontana-Uribe, B. A.; Inabez, J. G.; J. Hazard. Mater. 2012, 205, 208.

12. Kurniawan, T. A.; Lo, W.; Chan, G. Y. S.; J. Hazard. Mater. 2006, 129, 80.

13. Ahmed, F. N.; Lan, C. Q.; Desalination 2012, 287, 41.

14. Dewil, R.; Baeyens, J.; Neyens, E.; Environ. Eng. Sci. 2005, 23, 994.

15. Telles-Benatti, C.; Da Costa, A.C. S.; Granhen-Tavares, C.R.; J. Hazard. Mater. 2009, 163, 1246.

16. Amokrane, A.; Comel, C.; Veron, J.; Water Res. 1997, 11, 2775.

17. Zouboulis, A. I.; Chai, X. L; Katsoyiannis, I. A.; J. Environ. Manage. 2004, 70, 35.

18. Manning, D. A. C.; Bewsher, A.; J. Chromatogr. 1997, 770, 203.

19. Morais, J. L.; Sirtori, C.; Peralta-Zamora, P. G.; Quim. Nova 2006, 29 , 20.

20. Caramão, E. B.; Filho, I. N.; Muhel, C.; Quim. Nova 2001, 24, 554.

21. Bertazzoli, R.; Pelegrini, R.; Quim. Nova 2002, 25, 477.

22. Felipini, C. L.; Integração 2005, 41, 147.

23. Anyaegbunam, F. N. C.; International Journal of Engineering Research \& Technology 2014, 3,3 .

24. Ganguli, A.; Tarey, R. D.; Curr. Sci. 2002, 83, 279.

25. Venkatramani, N.; Curr. Sci. 2002, 83, 254.

26. Huang, H.; Tang, L.; Energ. Convers. Manage. 2007, 48, 1331.

27. Pourali, M.; The IEEE Xplore digital library - Institute of Electrical and Electronics Engineers 2010, 1, 125.

28. Gomez, E.; Rani, D. A.; Cheeseman, C. R.; Deegan, D.; Wisec, M.; A. Boccaccini, R.; J. Hazard. Mater. 2009, 161, 614.

29. Park, Y. J.; Heo, J.; J. Hazard. Mater. 2002, B91, 83.

30. Haugsten, K. E.; Gustavson, B.; Waste Manage. 2000, 20, 167.

31. Chu, J. P.; Hwang, I. J.; Tzeng, C. C.; Kuo, Y. Y.; Yu, Y. J.; J. Hazard. Mater. 1998, 58, 179.

32. Katou, K.; Asou, T.; Kurauchi, Y.; Sameshima, R.; Thin Solid Films 2001, 386, 183.

33. Leal-Quirós, E.; Braz. J. Phys. 2004, 34, 1587.

34. Yang, S. F.; Wang, T. M.; Lee, W. C.; Sun, K. S.; Tzeng, C. C.; J. Hazard. Mater. 2010, 182, 191.

35. Cheng, T. W.; Chu, J. P.; Tzeng, C. C.; Chen, Y. S.; Waste Manage. 2002, 22,485 .

36. Cheng, T. W.; Huang, M. Z; Tzeng, C. C.; Cheng, K. B.; Ueng, T. H.; Chemosphere 2007, 68, 1937.

37. Cubas, A. L. V.; Machado, M. M.; Machado, M. M.; Gross, F.; Magnago, R. F.; Moecke, E. H. S.; de Souza, I. G.; Environ. Sci. Technol. 2014, 48, 2853.

38. Silva, L. J.; Alves, F. C.; França, F. P.; Waste Manage. Res. 2012, 30, 1016.
39. Kim, S. W.; Park, H. S.; Kim, H. J.; Vacuum 2003, 70, 59.

40. Zhu, T.; Li, J.; Jin, Y.; Liang, Y.; Ma, G.; Int. J. Environ. Sci. Technol. 2008, 5,375 .

41. Kourti, I.; Rani D. A.; Bustos, A. G.; Deegan, D.; Boccaccini, A. R.; Cheeseman, C. R.; J. Hazard. Mater. 2011, 196, 86.

42. Kuo, Y. M.; Tseng, H. J.; Chang, J. E.; Wang, J.W.; Wang, C. T.; Chen, H. T.; J. Hazard. Mater. 2008, 156, 442.

43. Bonizzoni, G.; Vassallo, E.; Vacuum 2002, 64, 327.

44. Chang, J. S.; Sci. Technol. Adv. Mater. 2001, 2, 571.

45. Cheng, T. W.; Tu, C. C.; Ko, M. S.; Ueng, T. H.; Ceram. Int. 2011, 37, 2437.

46. Kogelschatz, U.; Plasma Phys. Controlled Fusion 2004, 46, B63.

47. Pfender, E.; Plasma Chem. Plasma Proc. 1999, $19,1$.

48. Cubas, A. L. V.; PhD Thesis, Universidade de Santa Catarina, Florianópolis, Brasil, 2004.

49. Allison, L. E.; Methods of soil analysis, American Society of Agronomy, Soil Science Society of America: Madison, 1965, p. 1367.

50. Associação Brasileira de Normas Técnicas. NBR 10005: Procedimento para obtenção de extrato lixiviado de resíduos sólidos. Rio de Janeiro, 2004.

51. Currie, L.; Horwitz, W.; IUPAC recommendations for defining and measuring detection and quantification limits; Analysis Magazine 1994, 22 , M24.

52. American Public Health Association - APHA; Standard Methods for examination of water and wastewater, $21^{\text {st }}$ ed., APHA/AWWA/WEF: Washington, 2005. 1368p.

53. Manual de métodos de análise de solo; Claessen, M. E. C., Barreto, W. O., Paula, J. L., Duarte, M. N., orgs.; Empresa Brasileira de Pesquisa Agropecuária, 1997.

54. Yabe, M. J. S.; Oliveira, E.; Quim. Nova 1998, 21, 551.

55. Tortora, G. J.; Funke, B. R.; Case, C. L.; Microbiology: An Introduction, $9^{\text {th }}$ ed., Benjamin Cummings: San Francisco, 2006, pp. 636-637, 727728.

56. Merten, G. H., Minella, J. P.; Revista Agroecologia e Desenvolvimento Rural Sustentável 2002, 3, 33.

57. Carvalho Filho, A.; Curi, N.; Marques, J. J. G. S. M.; Shinzato, E.; Freitas, D. A. F.; Jesus, E. A.; Massahud, R. T. L .R.; R. Bras. Ci. Solo 2011, 35, 793

58. Mancuso, M. A.; Azvedo, F. C. G.; Wastowski, A. D.; Fioreze, M.; Geol. USP, Sér. cient. 2016, 16, 85.

59. Silva, R. V.; Vendruscolo, R.; Santos, A. T.; Andrade, A. M. H.; XX Salão de Iniciação Científica, Universidade Federal do Rio Grande do Sul, Porto Alegre, Brasil, 2008.

60. CONAMA - Conselho Nacional de Meio Ambiente. Resolução n. 430, de 13 de maio de 2011. Regulates the conditions and effluent discharge standards, complements and modifies Resolution No. 357 of 17 March 2005, of Conselho Nacional do Meio Ambiente-CONAMA. Available in: http://www.mma.gov.br/port/conama/legiabre.cfm?codlegi=646, accessed April 2016. 